\title{
NOTICIA DE DIOS SIN VELADURA O EL ARTE POÉTICA DE JOSÉ ALCALÁ-ZAMORA
}

\section{Hernán SÁNCHEZ MARTÍNEZ DE PINILLOS}

University of Maryland

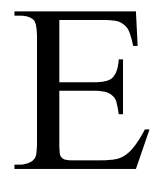
ste ensayo propone un ejercicio de comprensión del pensamiento poético de José AlcaláZamora y Queipo de Llano. En otro trabajo (Sánchez Martínez de Pinillos, 2015) hemos abordado el estudio del conjunto de su obra, cifrada en el volumen Noticia de mí (AlcaláZamora, 2012). Aquí analizamos el arte poética contenida en el mismo libro, en tanto resumen de la poética de su autor, en un aporte complementario a la apreciación íntegra de una obra de extraordinario valor estético.

Al comenzar la lectura de Noticia de mí nos encontramos con una sección introductoria titulada «Batuta y palabras de música», conformada por trece sonetos. En ellos no se habla del amor, la enfermedad o la muerte, ni de toda aquella multiplicidad de asuntos que suscitan la atención del poeta en el resto de esta colección. Aquí se habla sola y exclusivamente de la poesía como poesía, de la poesía como arte de expresión. Esta primera sección de Noticia de mí viene a ser el arte poética de la colección y de toda la producción lirica de José Alcalá-Zamora.

Para José Alcalá-Zamora la poesía es la objetivación lírica de la vida de la conciencia más lúcida y a la vez más profunda del ser humano. A través del acto creativo de la escritura de poemas, se expresa, se da a conocer la más plena autoconciencia de la experiencia que el sujeto vive; en la poesía la autoconciencia da noticia de sí al mundo. La poesía es el arte expresivo de la conciencia en dos aspectos: conciencia subjetiva del mundo, por cierto, y conciencia de sí o autoconciencia, que es la base sobre la que esa conciencia subjetiva del mundo es posible y asume sus cualidades específicas. Estas son las bases de la poética de José Alcalá-Zamora, y sobre ellas centraré la atención en este ensayo.

\section{El vértigo de la autoconciencia}

A fin de adentrarnos en el sentido de la poesía para Alcalá-Zamora es necesario partir de la teorización del proceso generativo de su escritura. Se trata de uno de los aspectos más elaborados en estos trece sonetos poetológicos de «Batuta y palabras de música», y a la vez uno de los aportes más 
originales a la reflexión sobre los procesos creativos del poeta. Esta reflexión, inscrita en la sección introductoria de Noticia de mí, constituye un auténtico manifiesto poético, en tanto experiencia culminante de la vida de la conciencia subjetiva. La poesía se concibe no exclusivamente como resultado de un proceso, sino como el proceso generativo mismo que la hace posible en toda su concreción material.

El proceso generativo de la poesía se desarrolla en un espacio temporal delimitado: en un espacio interior que permite al poeta aislarse del mundo y ensimismarse, reflexionar y escuchar la voz de la conciencia. En los sonetos de «Batuta y palabras de música» el espacio interior es la residencia privada del poeta o, por cierto, cualquier otro lugar en que el poeta se pueda apartar del mundo. Podemos imaginar a éste en su despacho, en su sala de estar y, en particular, así lo indican varios de los sonetos, en su dormitorio, pues muchos de ellos le son dictados por su inconsciente durante la vigilia, la duermevela o el sueño profundo. Y en un momento del día muy acotado, coincidente y coherente con la determinación espacial que venimos de describir: durante la noche, determinante temporal idóneo para ese ensimismamiento, esa escucha y ese diálogo del yo con su propia conciencia en su soledad más privada.

Una primera lectura de Noticia de mí, y de la poesía completa de Alcalá-Zamora, impresiona por la variedad de asuntos no sólo personales, sino eróticos, históricos, políticos, literarios, culturales y estéticos. Una vasta experiencia humana y social se condensa con distintas notas y acentos en estos sonetos. El poeta vive en el seno de la sociedad y su sensibilidad reacciona ante las múltiples incitaciones del acontecer cotidiano. El poeta se reconcentra en su espacio residencial privado porque es en ese espacio personal desde donde puede reflexionar, con la máxima libertad de conciencia. Esta determinación espacial es por ello decisiva: la libertad personal, la autonomía intelectual e imaginativa, el autoexamen, el inconsciente subjetivo, la compenetración meditativa en el sentido de la experiencia diurna, precisan de ese espacio íntimo en que la conciencia del sujeto se hace presente a sí misma en todo su potencial revelador.

La originalidad de los poemas de Noticia de mí, así como del manifiesto poético que es «Batuta y palabras de música», nace de la lucidez de la experiencia de la soledad nocturna en un espacio privado, y su estricta correlación con las operaciones de la autoconciencia. Los poemas surgen como emanaciones del interior nocturno de ese complejo espaciotemporal (el de la res cogitans de la interioridad y el de la res extensa que es la residencia privada) en el que opera la autoconciencia del poeta.

Los poemas de Noticia de mí son expresión del vértigo de una autoconciencia —en sintonía con su propio e insondable fondo - a través de cuyo tamiz la experiencia del poeta, su vivencia e intuición del mundo objetivo en su inmensa variedad, llega a nuestros oídos en la recitación, con una voz insobornable, irreductible, golpeando nuestra conciencia con incitaciones siempre originales e inquietantes. 


\section{Un soneto es un rayo}

La oscuridad de la noche induce en el sujeto una profundización del contacto con su propia conciencia y, mediatizado por esa autoconciencia nocturna, induce en él una compenetración ideal con la realidad de la experiencia del mundo vivida durante el día. La soledad y la oscuridad de la noche permiten el recogimiento y la conversación del sujeto consigo mismo, el contacto del yo con la radicalidad de su conciencia, y su meditación sobre la experiencia vivida en toda su variedad personal, social, política, estética y cultural.

De la sección introductoria «Batuta y palabras de música» se desprende que el poeta produce sus poemas en al menos cuatro estados diferenciados de conciencia, que se corresponden con cuatro momentos de la noche y con sendas gradaciones de profundización de la conciencia. Primero, la llegada de la noche hace posible la experiencia de la soledad nocturna; se trata de la noche previa a las horas de sueño, pero después de haberse retirado el poeta al recogimiento de su espacio privado, en un estado de ensimismamiento reflexivo y sereno.

En segundo lugar, algunos de los sonetos de «Batuta y palabras de música» sugieren que el poeta se encuentra en un estado insomne:

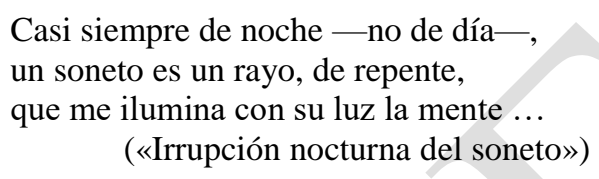

Se trataría aquí de estados de ánimo acordes con el insomnio: estados de exaltación, obsesión o de «posesión» (en un sentido muy preciso que explicaré en seguida) intelectual, emocional o pasional, que han impedido la conciliación del sueño y han hecho posible la generación de estados mentales caracterizados por la lucidez y exaltación propias del insomnio.

En tercer lugar, la experiencia creadora aparece ligada al entresueño o duermevela:

Luego en sobresaltada duermevela, cada verso me dicta y me desvela.

(«Irrupción nocturna del soneto»)

Se trata de un estado de conciencia despierta pero que sucede al sueño en el curso de la noche y que a su vez es seguido por el sueño. Es un estado de conciencia próximo al del sueño porque le sucede por contigüidad temporal y, podemos suponer, por transferencia de contenidos oníricos a los procesos de la conciencia lúcida. La cualidad particular de este estado de ánimo en el proceso de invención lírica reside en que si bien el sueño del que se despierta prepara el pensamiento poético, es la conciencia lúcida durante el momento de vigilia del entresueño la que le da forma y la que procesa el contenido de ese pensamiento en parte onírico. Este estado de conciencia admite sin duda grados diversos de lucidez próximos a la penumbra de la conciencia onírica, pero en que la voluntad consciente juega un papel en mayor o menor grado preponderante. Se trata de poemas de la conciencia lúcida marcados, en mayor o menor grado, por determinaciones oníricas: 
un soneto es un rayo, de repente, que me ilumina

[...] penetrándome desde el inconsciente mi inteligencia con terca isometría.

(«Irrupción nocturna del soneto»)

Por último, en cuarto lugar, en más de uno de los sonetos de esta sección liminar de Noticia de mí, el poeta, a quien podemos identificar con el hablante de cada uno de esos poemas, escribe en un estado de completa posesión onírica. El poeta despierta del sueño, pero el proceso generativo del poema ha tenido lugar durante el sueño profundo, y el poeta simplemente cumple la función de un amanuense de su propio inconsciente onírico, vertiendo al papel el dictado de ese inconsciente que le ha hablado en el sueño, mientras su conciencia ha permanecido completamente dormida:

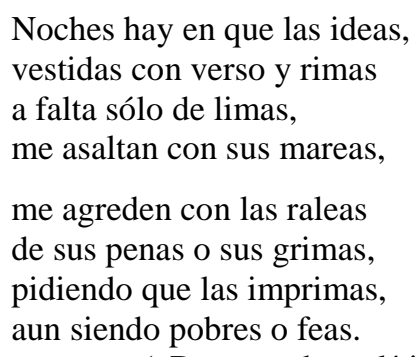

(«Despertadores líricos nocturnos»)

Además de establecer implícitamente estos cuatro estados de conciencia bajo cuyo ascendiente el poeta vive el proceso de su escritura, «Batuta y palabras de música» propone otras dos dicotomías: la de la condición en que el poeta genera su pensamiento lírico y en que escribe sus poemas, que puede ser activa o pasiva. El poeta puede estar, en mayor o menor grado, en posesión de sus facultades y ejercer las virtudes de esas facultades de manera deliberada. Esta condición activa del poeta en su ejercicio creativo resulta obvia en el primer estado de conciencia que describimos arriba como de ensimismamiento lúcido y sereno. Otro tanto se puede decir del segundo estado, el de insomnio, en que es justamente esa condición activa en grado extremo la que le impide conciliar el sueño, y lo mantiene alerta en horas altas de la noche y de la madrugada. La actividad de la conciencia del poeta insomne es por ello de un grado de intensidad mayor al del primer estado.

El tercer estado de conciencia, el de la duermevela, viene a ser un estado que podemos llamar de penumbra de la actividad deliberada de la conciencia lúcida, pues esa actividad está en parte marcada por la actividad onírica que la prepara, de modo que si bien el poeta desarrolla su pensamiento poético durante el lapso de vigilia del entresueño de manera activa, deliberada y consciente, todo este proceso, marcado fuertemente por la influencia onírica que le antecede, lo podemos caracterizar como la de un «iluminado» en el sentido de una conciencia iluminada por el propio inconsciente onírico que le es precedente y, respecto de su autoconciencia, trascendente.

En la conciencia lúcida del poeta, el pensamiento onírico del sueño parece extenderse en cierto grado al momento de la vigilia: la actividad de la conciencia parece proseguir ininterrumpida entre el sueño y la vigilia, entre el inconsciente y la autoconciencia, sin que la conciencia lúcida en la vigilia, 
luego del despertar, interrumpa ese proceso. Se trata aquí de la continuidad de los procesos propios de la conciencia onírica en la vigilia pasajera de la conciencia.

Por último, el cuarto estado de conciencia, el del sueño profundo en que el inconsciente opera de manera exclusiva según sus propias leyes, supone la pasividad absoluta de la conciencia: al despertar, el poeta no hace más que verter al papel el dictado del inconsciente.

\section{Ética poética}

A esta primera dicotomía agregamos ahora una segunda que lleva aún más lejos la originalidad del aporte teórico del poeta a la comprensión de ese proceso poético. Se trata en este caso de lo que podemos denominar una dicotomía volitiva. Esta dicotomía constituye el aspecto más idiosincrásico del poeta, quien en el proceso de generación de su escritura se muestra por lo general anuente, pero muchas veces todo lo contrario, renuente a poner por escrito su pensamiento poético, renuente incluso a dar curso libre a ese pensamiento poético incontenible e irresistible. En la duermevela y, en particular, al despertar exaltado, o incluso violentado, del sueño profundo, con el poema ya íntegramente compuesto por el inconsciente durante el sueño, el poeta tematiza, particularmente en «Despertadores líricos nocturnos», su renuencia ocasional, pero visceral, a transcribir el dictado de su inconsciente. Es de notar que incluso en estos momentos de conflicto entre el proceso de generación onírica del pensamiento poético inconsciente y la manifiesta renuencia del poeta a obedecer la compulsión creativa de ese inconsciente al despertar, el poeta no deja de poner por escrito ese dictado, es decir, no deja de cumplir su función pasiva y, en tales casos, renuente, de amanuense de su propio inconsciente onírico, respecto del cual parece sentir cierta enajenación. Éste es uno de los aspectos más originales del arte poética de José Alcalá-Zamora.

Es este sentido de obligación que mueve al autor a poner por escrito incluso aquellos poemas que desearía no tener que transcribir. Este sentido de responsabilidad ante el dictado del inconsciente, la enajenación respecto de la compulsión del inconsciente onírico, significa que el acto creativo del poeta constituye para él un imperativo moral.

Esta filiación entre la actividad creadora del inconsciente en que la autoconciencia del poeta se encuentra en un estado de absoluta pasividad, y la autoconciencia del poeta que despierta con el producto lírico de su propio inconsciente ya fabricado, y respecto del cual siente cierta enajenación y a veces una declarada renuencia a cumplir su dictado, apunta por un lado a una ética de la conciencia personal y, por otro, al sentido más abarcador de la conciencia nocturna. En el proceso generativo se verifica la adecuación de la conciencia nocturna profunda en su cuádruple manifestación —el complejo orgánico de la conciencia lúcida y el inconsciente onírico en los cuatro estados que hemos descrito- a la verdad absoluta de la que esa conciencia es capaz en sí misma. Éste viene a ser el fundamento de todo sentido moral de esta conciencia personal. La conciencia nocturna como complejo de sus dimensiones consciente e inconsciente, activa y pasiva, anuente y renuente, es su propia 
evidencia, su propia norma cognoscitiva y moral: es su propio a priori, entendido éste en su aspecto intra-trascendente, como expresión de la auto-conciencia más radical y absoluta de la persona.

En contraste con la conciencia diurna del poeta, el complejo de la conciencia nocturna en sus cuatro manifestaciones concretas puede ser imaginado como emblema de la máxima individualidad de pensamiento y la base de la personalidad imaginativa e intelectual del poeta.

En razón de ello, no sorprende que éste introduzca el concepto de «Dios» al describir ese contenido profundo, absoluto, radical e intra-trascendente de todos sus sonetos y al que éstos dan expresión:

Mayor que el cuadro o la pintura, es noticia de Dios sin veladura que misterios sugiere y desentraña.

(«Soneto al soneto»)

\section{Poesía justiciera}

Hemos tratado hasta aquí el complejo de la conciencia nocturna como estrato más hondo del sentido de la verdad cognoscitiva y moral: el pensamiento poético es inmanente a la conciencia nocturna y, en especial, al inconsciente onírico, pero sería trascendente ante la conciencia que hemos llamado «diurna» para distinguirla del complejo cuaternario de la conciencia nocturna. La correlación entre esa inmanencia intra-trascendente del pensamiento poético y la «noticia de Dios sin veladura» parece suponer, en la imagen que el poeta tendría de sí mismo y de su quehacer creativo, el paralelo con la función social que procuraban cumplir los profetas hebreos del Antiguo Testamento.

Hablábamos de la renuencia que por momentos sentía el poeta de trasladar al papel el dictado de su conciencia nocturna y de su conciencia onírica en particular. A esta luz, al menos dos de los profetas de la Biblia hebrea se nos vienen a la mente, dos profetas renuentes o, al menos, inicialmente renuentes, a cumplir su vocación ineludible de transmitir la verdad trascendental a su pueblo. Pensamos en Jonás y en Jeremías. Ambos experimentan la superación de su renuencia inicial que les permite volverse conscientes no sólo del absoluto de la revelación divina que experimentan, sino, con ello, del sentido místico de la responsabilidad que tienen de comunicar el mensaje de esa revelación a la sociedad que ha perdido el camino o que está en peligro de extraviarse y padecer o su destrucción (como es el caso de Nínive, ciudad en la que Jonás lleva a cabo su ministerio) o su sometimiento y cautiverio (como, en el caso del ministerio de Jeremías, es el caso de Judá antes y luego de caer bajo el dominio babilónico).

Al igual que estos profetas hebreos, el profeta secular cuya voz alienta en Noticia de mí se muestra renuente a veces a cumplir su vocación poética, pero de igual suerte que esos profetas hebreos tiene clara la absoluta importancia social de su palabra, el sentido de absoluta responsabilidad personal de comunicar con fidelidad el dictado preciso de su conciencia nocturna a la comunidad. El poeta expresa la verdad para él absoluta de las floraciones poemáticas de su conciencia nocturna, conscientes o inconscientes, y esa verdad posee para él una autoridad moral que lo compromete existencialmente 
como portador de ella ante la sociedad. Pero en el seno de la sociedad acechan la mentira, la inhumanidad, la autocomplacencia, la cobardía, la venalidad y, en una palabra, la injusticia. Y es contra esta acechanza inagotable que el poeta lleva adelante su quehacer lírico postulando las verdades intratrascendentes de su conciencia como un mentís a las perversiones morales, intelectuales, culturales, estéticas e ideológicas de la comunidad.

Estas reflexiones nos permiten abordar el marcado énfasis polémico de todos estos sonetos: el poeta no sólo piensa, sino que propone, promueve y defiende una verdad que es suya pero que reclama como norma ante los demás integrantes de la comunidad. Esta actitud fundamental se aprecia en el aire desafiante de los sonetos de esta colección y de manera especial en una pieza decisiva de «Batuta y palabras de música» como es «Poesía justiciera»:

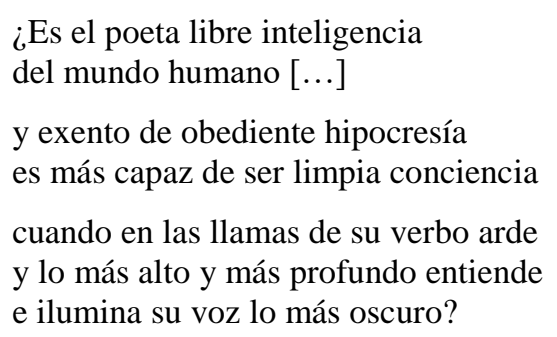

La radicación interior y trascendente de la verdad del poeta infunde en éste una pasión de justicia intelectual y moral. La intuición de verdad o, para ser más exactos, la profunda convicción de ser un privilegiado portador de la verdad, inspira en el poeta un sentido vehemente de justicia, pues esa certeza de verdad se rebela contra toda violencia - mentira, distorsión, perversión, falsedad, abuso, inexactitud, manipulación sofística, intelectual, teológica o ideológica- La verdad - a la que con pasión y asertividad muchas veces desafiante da expresión el poeta- destaca por la lucidez de su convicción personal y de su radicación en la conciencia más profunda.

Por ahora, sólo constatamos la correlación entre, de un lado, la apelación a una razón íntima y trascendente en la que el poeta sustenta la validez y la intensidad de su pasión cognoscitiva de la realidad, y el sentido de justicia arraigado en esa verdad interior. La poesía, así concebida y así vivida, es para el poeta la máxima fuente de autoridad moral del ser humano. La seriedad del gesto con que interpela al lector a nivel imaginativo, cognoscitivo, intelectual y ético, es imposible de soslayar. El poeta no sólo afirma con una seguridad desafiante esa certidumbre emanada de su propia autoridad imaginativa, intelectual y moral, sino que, junto con ello, percibimos en esos poemas la verdad metafísica de su sentido expresivo.

\section{Privilegio lírico}

La certeza en sus convicciones y el aire desafiante se respiran de inicio a fin de Noticia de mí, pero afloran de manera palmaria en varios sonetos que describen lo que el poeta llama el «privilegio» y la «presunción» de la poesía. Detengámonos un momento para reflexionar sobre el sentido algo excéntrico de estas dos valoraciones que el poeta hace de la propia actividad creativa. 
Pues, a decir verdad, no solemos asociar la poesía, y menos aún la poesía lírica, ni con la presunción ni con el privilegio social - a diferencia de la oratoria forense o deliberativa, el derecho civil, la filosofía, la teología, la historiografía, el discurso científico e incluso el teatro, desarrollado en los espacios públicos privilegiados-. Éstos no sólo ocupan un lugar social y público; también ostentan un poder de persuasión. Otro tanto se puede afirmar del arte cinemático, de la novela, del cuento y del ensayo periodístico, géneros concebidos y dirigidos al consumo de las masas. Se trata de géneros, por comparación con la lírica, que ocupan un lugar privilegiado en la sociedad y que de hecho van dirigidos a un público multitudinario.

Por contraste, en nuestra época posmoderna y, habría que añadir, desde la invención de la imprenta, que sustrajo al juglar o al trovador de los espacios populares y cortesanos donde ejercía su arte expresivo, la poesía lírica ha sido y sigue siendo el menos presuntuoso y el menos privilegiado socialmente de los géneros literarios y de las formas de expresión artística. Su campo de acción se reduce a las dimensiones de la privacidad e interioridad del lector solitario. El campo de referencia de la lírica es la incierta subjetividad del ser humano. Sus verdades no apuntan, en lo esencial, a realidades exteriores mensurables y cuantificables, ni a imágenes plásticas ostentosas por definición, ni a ideas traducibles a definiciones o a descripciones verbales, o a sistemas metafísicos o ideológicos, sino a las verdades muchas veces irracionales o sencillamente no racionales de la conciencia subjetiva, irreductibles a la mediación científica, a la conceptualización filosófica, a las lógicas narrativas, y a la exteriorización plástica de tipo teatral, fílmico, pictórico o escultural, y a los géneros literarios de difusión masiva, como la novela, el cuento y el ensayo.

Es por ello que los sonetos «Privilegio lírico»y «Presunción lírica» constituyen sendos desafíos a nuestra idea normativa de lo que es la poesía lírica y de su alcance en nuestra conciencia personal y en el seno de la comunidad. Me parece que el poeta no sólo es consciente del privilegio que representa la poesía como género de expresión y de su poesía en particular, y no se resta de presumir expresamente de ello, sino que pretende además que la poesía, y su poesía en particular, reivindique para sí un lugar en la comunidad no menos relevante, quizás más relevante aún, que el de los otros géneros literarios y artísticos que acabamos de mencionar. A la pregunta de dónde procede ese «privilegio» y qué justifica semejante «presunción» para uno de los géneros de expresión, como diría Antonio Machado, más «sutiles» e «ingrávidos», sino el más sutil e ingrávido de todos, hemos intentado una respuesta al describir la radicación intra-trascendente de las verdades a que da expresión y la convicción de la verdad que emana de la interioridad más profunda y más lúcida del poeta.

\section{Una armoniosa luminosidad}

Si pudiésemos describir la forma en que esa verdad profunda emana de la conciencia nocturna del poeta lo podríamos hacer con recurso a una sinestesia y decir que cada poema creado por esa conciencia nocturna posee la forma de una «armoniosa luminosidad». Si volvemos nuestra atención sobre el conjunto de sonetos de Noticia de mí, podemos apreciar que este efecto de armoniosa 
luminosidad de los poemas del inconsciente onírico parece ser propio no sólo de aquellos sonetos que justamente han sido redactados por el inconsciente durante el sueño sino también de todos los demás sonetos creados por esa conciencia nocturna - en sentido estricto, no podemos distinguir unos de otros en esta colección pues, por lo general, no se nos dice cuáles han sido escrito durante el sueño y cuáles durante la vigilia nocturna-. Creo no equivocarme al afirmar que la poesía de José Alcalá-Zamora se caracteriza en términos generales, esto es, como cualidad que se hace extensiva a todos sus poemas, por su armoniosa luminosidad.

El poeta usa estas dos metáforas a lo largo de «Batuta y palabras de música» para describir la experiencia que tiene de su autoconciencia y de sus significativas determinaciones espaciotemporales: el espacio privado por antonomasia (la residencia personal) y la noche. La noche no sólo es oscura sino silenciosa y es por ello revelador que las dos metáforas preponderantes que en «Batuta y palabras de música» describen el contenido y el sentido de esta poesía que nace en el silencio de la noche sean «luz»y «música»:

\section{Hirió la luz sonora las tinieblas oscuras, alzó hasta las alturas su música cantora. $(\ll$ Luz sonora»)}

Estas metáforas describen la poesía del pensamiento que se objetiva en Notica de mí, pero en un sentido más primario describen la manera en que el poeta vive las operaciones de su propia conciencia nocturna: como luminosidad y como armonía, como visión y como escucha. Ambas metáforas expresan el absoluto de esa visión y esa escucha de la verdad, de ese «Dios» del que el poeta da noticia. Hemos hablado de la trascendencia interior de esa visión y de esa escucha de la verdad absoluta de la conciencia personal. Hemos dicho que esa verdad absoluta de la conciencia personal es trascendente de la autoconciencia lúcida, pero inmanente al inconsciente onírico del poeta -interior y trascendente en ese sentido estricto-. Y luego hemos acercado la conciencia nocturna no inconsciente (en los estados de ensimismamiento nocturno, de insomnio y de duermevela) al inconsciente onírico del poeta: la trascendencia de la verdad absoluta radicada en el inconsciente onírico, relativa a la conciencia lúcida, caracterizaría a esta misma conciencia lúcida nocturna. Sería la cualidad nocturna del cuádruple complejo de la conciencia creativa del poeta la que explicaría ese acercamiento de los procesos conscientes nocturnos a los procesos oníricos inconscientes. El sentido de la doble metáfora - luz y música - que describe esa trascendencia intima, en sentido lato, consiste en describir el absoluto que para el sujeto representa este cuádruple modo en que su conciencia interioriza y reflexiona sobre la experiencia y la realidad, tanto de sí misma como del mundo externo. Ambas metáforas, propias de la poesía mística, evocan la seriedad, la elevación, la exaltación y la intensidad del sentido que la radicación interior y trascendente de la verdad tiene para el poeta. Luz y música describen, una el impacto de esa verdad en la conciencia poética, y la otra la forma que la verdad de la conciencia personal asume al objetivarse como pensamiento concreto en sonetos. 
Noticia de Dios sin veladura o el arte poética de José Alcalá-Zamora

\title{
Poesía apolínea
}

La luminosidad y la musicalidad o armonía del pensamiento nocturno del poeta permiten describir Noticia de mí como una poesía apolínea sui generis. En particular, como poesía apolínea del absoluto de la conciencia. El poeta viene a ser, por analogía con el dios solar pagano de los antiguos griegos, oráculo de su inconsciente y de los procesos de su conciencia nocturna.

Como objetivaciones concretas de las «armonías luminosas» del pensamiento, los sonetos de Noticia de mí viene pueden describirse como una epifanía de esa conciencia nocturna. Cada soneto representa una epifanía intelectual, y el efecto estético que produce es de claridad y lucidez intelectual e imaginativa.

En aparente contraste con esta propuesta de la poesía como oráculo de la conciencia intratrascendente, resulta revelador el uso del vocablo «párrafos» que hace el poeta al describir sus poemas:

\author{
Voy ensanchando mi vocabulario; \\ las sintácticas odio imprecisiones; \\ sólo el párrafo largo me contenta. \\ («Privilegio lírico»)
}

Este párrafo largo que es para él el soneto desmitifica toda asociación entre la conciencia poética nocturna y onírica con una poesía de la ensoñación o del ensueño, como la que propone Paul Verlaine y, en nuestra tradición hispánica, Rubén Darío. La musicalidad de los sonetos de Noticia de mí no procede, propiamente hablando, de la explotación de las figuras de ornato y los recursos formales de la poesía, en especial los de repetición, aquellos que permitieron a Verlaine y a Darío construir en cada pieza lírica una caja de resonancias sugestiva de un estado anímico, aunque - y ésta es la notable virtud de la poesía simbolista - la sugestión de esos estados es sin duda la asombrosa obra creativa de la facultad poética del artífice lírico. Cuando Verlaine exige «De la musique avant toute chose», está pensando en potenciar las posibilidades musicales de las palabras, el verso, la prosodia, la rima, la estrofa y la sucesión de estrofas. Este concepto simbolista de una poesía musical es ajeno a la «música habladora» y a la «palabra canora» («Luz sonora») de Notica de mí, expresiones, ambas, que hacen hincapié en la poesía como expresión del pensamiento profundo, no como sugestión de estados anímicos o psicológicos.

Por contraste, la poesía de José Alcalá-Zamora habla más que sugiere. Por ello, el poeta parece apuntar a otro tipo de armonía o musicalidad, como asimismo a otro tipo de luminosidad poética, cuando describe sus producciones líricas - en términos propios del lenguaje discursivo, prosísticocomo «párrafos». Contra la musicalidad sugestiva de estados de ánimo y de conciencia, contra el precepto «De la musique avant toute chose» formulado por Verlaine y asimilado por los poetas simbolistas, los sonetos de José Alcalá-Zamora responden a una poética de la precisión intelectual, del concepto claramente plasmado, de un pensamiento cuya discursividad, cuya exposición posee una musicalidad sui generis intrínseca, clara y nítida, como el golpe de luz que el poeta recibe desde el fondo de su conciencia. 
Los recursos formales la expresión son para Alcalá-Zamora vehículos de un pensamiento único y lúcido. El precepto contrastante — respecto de un Verlaine - que parece formular el poeta sería el siguiente: «antes que nada, la concreción lírica de un pensamiento único y singular lúcidamente expuesto; antes que nada, una expresividad precisa y distintiva en cada poema; antes que nada, un poema inteligente y luminosamente claro».

Es por ello que el soneto, imaginado como «párrafo largo», provee a un pensamiento único, discreto, específico, la forma idónea para que éste se despliegue como unidad de sentido, pues la estructura lógico-discursiva del soneto es idónea para la expresión y objetivación concreta de un único pensamiento. Si bien José Alcalá-Zamora explota las múltiples posibilidades estructurales de exposición de una epifanía del pensamiento del soneto como forma lírica, una posibilidad es aquella en que los cuartetos presentan el pensamiento intuido en abstracto por la conciencia nocturna y los tercetos lo precisan, ejemplifican y materializan. Los recursos de repetición (sucesión de cuartetos, sucesión de tercetos, sucesión de versos endecasílabos —u octosílabos-, rimas externas e internas, aliteraciones, anáforas, etc.) y los tropos (metáfora, alegoría, metonimia, sinécdoque, énfasis, hipérbole etc.) iluminan las epifanías de cada soneto mediante su reforzamiento formal y figurativo.

A esta luz podemos entender que el poeta afirme en la pieza titulada «Nadie tantos» que el soneto es la más «perfecta hechura», y que en «Soneto blanco al endecasílabo» amplifique este pensamiento correlacionando esa «perfecta hechura» justamente con el testimonio que de esa perfección formal da la conciencia al verse sobrecogida por el poder del inconsciente o de la conciencia nocturna en la «armonía de números sagrados».

El soneto es una forma idónea para expresar un pensamiento poético-discursivo único, emanado del inconsciente numinoso y trascendente del que procede el impulso expresivo del poeta durante la noche. Esta correlación entre expresividad poético-discursiva de la conciencia nocturna objetivada en el soneto nos permite describir éstos no sólo como «párrafos» sino, quizá con no menor pertinencia, como «prosas en verso», para señalar la sutil diferencia que estos sonetos de Alcalá-Zamora marcan respecto de la tradición simbolista del «poema en prosa».

Así entendido, el soneto sería para José Alcalá-Zamora la forma cabal de expresión que emana directamente de ese misterio insondable que es la conciencia nocturna en sus cuatro manifestaciones (ensimismamiento nocturno, insomnio, duermevela, sueño profundo). No es producto de un artificio del todo deliberado, no es un artefacto hechizo: es una forma orgánica que surge de golpe en toda su madurez plástica, como Atenea de la testa de Zeus, ya del inconsciente onírico del poeta, ya de la exaltación de su conciencia nocturna. El poeta retoca esa forma movido por el inconsciente, de manera que es éste el que realiza la depuración final:

Luego en sobresaltada duermevela, cada verso me dicta y me desvela: rectifica, corrige, cambia muda cada palabra hasta encontrar la exacta, la única posible, la que impacta, la que la esencia lírica desnuda. 
O por procesos conscientes, como el autor nos lo dice en el último soneto de esta sección: «Perfección y éxtasis del soneto»:

\footnotetext{
Tu perfección, soneto, me enamora, tan sólo soy feliz mientras te escribo en esa, más o menos, media hora que dura tu volcán generativo, y cuando, al fin, mi mano correctora aprueba tu perfil definitivo.
}

Pero, en lo esencial, la forma del soneto y su contenido irrumpe sobre la conciencia desde el inconsciente como una fuerza propia, que el poeta experimenta como irrupción involuntaria: una fuerza poderosa se impone, desde su «inconsciente» o desde su conciencia nocturna, sobre su conciencia lúcida, que reconoce la verdad luminosa y armónica de esa forma y de ese contenido, y la vierte al papel transmitiéndonos el mensaje de verdad desde ese origen nocturno consciente o inconsciente que trasciende a la conciencia diurna del mismo sujeto.

\section{Ráfagas de viento}

El soneto es para este poeta la forma natural en que se expresa el inconsciente o la conciencia nocturna entendida de manera orgánica, a saber, una conciencia que opera en sintonía, o colabora, con el inconsciente, cuyos procesos naturales, irresistibles e irreprimibles obedece y luego perfecciona en el proceso de edición final. Pero ¿cómo puede ser que la conciencia nocturna del poeta y, en especial, su inconsciente onírico produzca de manera natural, y muchas veces — si no las más— sin esfuerzo casi, una forma lírica tan compleja como es el soneto? ¿Cómo podemos entender o siquiera concebir la «naturalidad» del soneto como medio de expresión del inconsciente onírico y de la conciencia nocturna en las otras tres variedades que hemos identificado? Cada pensamiento poético individual encuentra en esta forma el medio idóneo — su correlato formal connatural— para objetivarse y expresarse de manera cabal. El pensamiento nocturno reconoce en la forma del soneto la forma ideal de una epifanía. Éste brota de su conciencia nocturna y se manifiesta en la forma de un soneto como un fogonazo o, según el poeta lo describe en diversos sonetos de esta sección introductoria, como «ráfagas de viento» («Artes hermanas»), «un rayo» («Irrupción nocturna del soneto»), «instantes interiores», «nocturnas campanadas»o un «trueno azul» («Soneto blanco al endecasílabo»). Y el soneto es la forma que mejor pone de manifiesto esa ráfaga, ese rayo, ese instante interior, esa campanada, ese trueno o rayo que es cada epifanía del pensamiento. El fulgor de la epifanía intelectual dura lo que la lectura (y la comprensión recta) del soneto.

El inconsciente no opera por inercia ni como sujeto pasivo de impulsos pre-racionales, y menos aún como mero depósito de recuerdos, imágenes y símbolos, ni de escenas aleatorias o caprichosas —al estilo surrealista—, sino todo lo contrario. Parece más bien poseer los más altos grados de lucidez, inteligencia, penetración intelectual, reflexión, creatividad, imaginación, expresividad, sentido 
estético, sofisticación, todo ello inmanente a ese inconsciente y a esa conciencia nocturna trascendentes a la conciencia diurna.

Noticia de mí propone así una poética romántica del sueño y del ensueño, aunque se trata de una poética romántica sui generis. El sueño, la noche, la oscuridad, la soledad y aislamiento de la conciencia del poeta, como en los románticos estudiados por Albert Béguin, son los manaderos de los poemas de Alcalá-Zamora. El poeta no compone ningún himno a la noche como hizo Novalis, pues semejante himno presupondría un distanciamiento racional respecto de las fuentes irracionales, oníricas o semi-oníricas, nocturnas, de las epifanías de su pensamiento poético. Pero podemos aventurar el acercamiento entre los sonetos de esta colección con un poema romántico muy cercano en sus procesos generativos: el «Kubla Khan» (1797) de Samuel Taylor Coleridge. Este poema es fruto directo de una irrupción nocturna, un despertador lírico, de una fuerza irracional, onírica, que compele al poeta a escribir el poema escuchado o compuesto durante el sueño, luego de haber despertado. Varios poemas de Noticia de mí — podemos especular sin temor a equivocarnos — son, como «Kubla Khan», poemas de escucha de un inconsciente que trasciende a la conciencia diurna del poeta.

\section{La exclusividad del soneto: diversidad y potencia}

Un aspecto capital de la poética propuesta por Alcalá-Zamora es el de la exclusividad del soneto como forma predilecta de expresión lírica, no sólo en Noticia de mí, sino en el grueso de su vastísima producción lírica. Ya hemos visto por qué el soneto es la forma idónea para expresar esos «instantes interiores» que son cada una de las epifanías del pensamiento del poeta. No obstante, esta exclusividad formal constituye a todas luces una limitación. El poeta ha elegido —o el inconsciente le ha impuesto- expresarse sólo en sonetos. Todo lector, todo amante de la poesía lírica, reconoce en el soneto una de las numerosas formas de expresión lírica. Previo a la introducción en España de las formas italianizantes, entre las que se destacaba el soneto, las formas líricas autóctonas eran el romance, las redondillas, las décimas, y otras formas de arte menor. El arte mayor tenía a su vez una aplicación lírica, no sólo narrativa, como se aprecia desde Berceo. Boscán y Garcilaso introdujeron en España las formas italianizantes de la lira, los tercetos encadenados, la octava real, las silvas, las odas $\mathrm{y}$, en particular, el soneto.

Con posterioridad, el romanticismo y el modernismo hispano iniciado por Darío enriquecían el repertorio de formas líricas, al introducir, inspirados en los románticos y los simbolistas franceses, poemas líricos formados por una sucesión, más o menos breve o extensa, de estrofas de diverso número de versos, entre ellas los cuartetos y los tercetos, así como poemas de mayor o menor extensión formados de pareados. El mismo Darío utiliza una gran variedad de formas y géneros líricos y para él el soneto es sólo una de varias modalidades de la que dispone en su paleta de formas líricas. Este contexto histórico nos permite reconocer el primer problema estrictamente formal que nos propone José Alcalá-Zamora en Noticia de mí: la exclusividad desconcertante del soneto como forma de expresión de su conciencia subjetiva. 
La uniformidad y exclusividad del género lírico escogido atenta contra la variedad, necesaria, parecería, para romper la monotonía formal de una abundante colección de poemas. Me atrevo a decir que esta cuestión es evidente para todo lector de Noticia de mí. Es una cuestión no sólo ineludible, sino imprescindible resolver para poder entender estos poemas y con ello apreciarlos debidamente. El poeta, o el inconsciente del poeta, se muestra recalcitrante en esta materia y el lector se ve ante la necesidad de comprender sus razones.

La cuestión de la exclusividad del soneto plantea la posibilidad de una repetitividad formal. A esta objeción caben al menos tres respuestas. En primer lugar, la forma del soneto responde a la poética de José Alcalá-Zamora en la medida que privilegia la expresión de los «instantes interiores» de la conciencia nocturna, expresada justamente en pensamientos unitarios, en que la conciencia profunda se vive a sí misma como instantes discretos, autónomos, diversos, únicos. Y la sucesión de sonetos que expresan estos instantes diversos e interiores de la conciencia nocturna conforma una coherencia de pensamiento; este pensamiento fragmentario que representa cada soneto, en tanto expresión lúcida e intensa de la conciencia, se objetiva de modo cumulativo en cada sección de cada libro y en la producción total del poeta.

En segundo lugar, la siempre diversa estructuración de cada epifanía del pensamiento en un soneto específico logra garantizar el máximo efecto de diversidad dentro de una forma lírica particular. Pienso que todo lector confirmará en su lectura de Noticia de mí la impresión de que cada soneto de esta colección es a tal punto diverso, diferente, heterogéneo respecto de cada uno de los demás, que la experiencia de la lectura es de una variedad y riqueza de conciencia que resulta simplemente asombrosa.

\section{Monstruo de la naturaleza}

Y esto nos lleva al tercer punto: la virtud mito-poética de José Alcalá-Zamora le confiere al soneto la categoría de vehículo idóneo que permite dar expresión a cada epifanía del pensamiento y, con ello, hace posible la plasmación verbal de la inagotable variedad de contenidos de la conciencia nocturna, honda, del ser humano. La uniformidad del soneto como género lírico es la condición formal que hace posible la máxima variedad de epifanías de pensamiento y con ello la objetivación sobreabundante de la versatilidad imaginativa del poeta. El efecto estético de la lectura comprensiva de Noticia de mí en el lector es el de una potencia creativa proteica que ofrece una experiencia poética nueva en cada soneto. La consecuencia de este hecho es que el poeta ha encontrado en su forma particular y reiterativa de expresión la manera idónea de transmutar la plena lucidez de su conciencia en exuberancia creativa.

José Alcalá-Zamora parece haber dado con la clave poética de la liberación radical de la conciencia, y esa liberación le permite pensar la forma del soneto con una vitalidad ubérrima. La conciencia, que se vive a sí misma en instantes interiores, es un manadero de creatividad omnímoda en sus objetivaciones concretas. Quizá como en ningún otro poeta, Alcalá-Zamora transforma el soneto 
en canal de transmisión de la energía vital de la mente humana sin represiones ni frenos, de forma absolutamente liberada e iluminada. Como en Lope, Quevedo, Rubén Darío y Neruda, reconocemos en José Alcalá-Zamora a un poeta cuya creatividad lírica corre parejas con la totalidad de su biografía pasional e intelectual. Este hecho sitúa a nuestro poeta en la constelación formada por la alineación sideral de cada uno de esos «monstruos de naturaleza» de la poesía en lengua española de los últimos cinco siglos.

\section{Una voz profética y universal}

Concluyo estas reflexiones en torno a la poética inscrita en la sección «Batuta y palabras de música» de Notica de mí llamando la atención sobre el espíritu profético que alienta en la poesía de José Alcalá-Zamora. El manadero de espiritualidad que esa producción lírica pone de manifiesto es manifiestamente secular. Cualquier carácter profético que se pueda reconocer en nuestro poeta sería de corte secular. En particular desde el Renacimiento, y ya de lleno desde el Romanticismo, el poeta ha sido elevado por filósofos y teóricos de la literatura a una condición suprema por la importancia de su quehacer creativo, y esto paradójicamente en un época de la historia, la Modernidad y ahora la asî llamada Posmodernidad, en que su reconocimiento social es cada vez menor, prácticamente marginal, y en que su voz es cada vez menos escuchada por el común de la gente. Esta elevación del poeta y de sus creaciones son formuladas en los albores del Romanticismo por un filósofo como Schelling y por un poeta como Shelley, quien en su célebre A Defence of Poetry reconoce en ellos a los «unacknowledged legislators of the world» (Shelley, 1821: 118), expresión que da cuenta de la paradoja a que hemos aludido: los poetas serían los legisladores del mundo, pero no se les reconoce como tales. El problema de la relevancia de la palabra del poeta en nuestros días, por lo tanto, es doble. Por un lado, no se le reconoce ninguna autoridad efectiva, pues su palabra no rebasa el ámbito de lo personal, es decir, cualquier verdad que pretenda representar no es más que la expresión de su subjetividad y de las limitaciones insalvables de ésta. Por otro, cuando alcanza la lucidez visionaria de los grandes poetas, y cuando esa lucidez es reconocida en las sombras de la sociedad por los pocos que la saben escuchar o que necesitan escucharla, su palabra se convierte nada menos que en el pilar moral y espiritual del individuo, que descubre en ella su poder revelador, aquel poder eficiente de «fundar el ser por la palabra», que Heidegger reconocía en ellos.

De un lado, entonces, el subjetivismo de la palabra poética, que la relativiza de manera insalvable; de otro, el poder espiritual de esa misma palabra, poder sobre el cual se sostiene el ser metafísico y moral del mundo en la conciencia de los pocos lectores que en la España y en el mundo de hoy acceden a ella. El repaso que hemos hecho de la estructura de la conciencia lírica expuesta en la sección introductoria de Noticia de mí nos advierte que si bien se trata necesariamente de una conciencia subjetiva, lo es de una manera singular. Hemos intentado mostrar esto al describirla como una conciencia nocturna en que la lucidez de la autoconciencia está traspasada en mayor o menor grado por el propio inconsciente; esta conciencia posee una cualidad íntima y trascendente que la pone en 
contacto con los estratos y los móviles más recónditos del espíritu humano. Pero lo que se vive en las profundidades de semejante conciencia es el ser real de la experiencia vivida durante el día y, con él, el sentido y justa valoración de esa experiencia.

Al leer Noticia de mí, y esto se puede hacer extensivo al resto de la producción lírica de José Alcalá-Zamora, presentimos que la subjetividad expresada en sus sonetos nos revela en toda su radicalidad la verdad objetiva de cada experiencia abordada por el poeta, tanto la verdad referente a él mismo como individuo, como a la verdad de las experiencias que el resto de nosotros compartimos con él como habitantes de un mismo mundo temporal y cultural. Esta impresión de estar tocando las cosas y las vivencias tratados en los poemas, en su propio ser, en su radical veracidad, es lo que hace de la poesía intensa y privilegiadamente subjetiva de José Alcalá-Zamora una palabra y una voz al mismo tiempo española y universal.

Un versículo de la Biblia describe con gran precisión lo que podemos llamar la fisiología de la conciencia humana. Se trata del Salmo 18, versículo 3, el cual cito en la versión universal de la Iglesia Católica:

Desde la perspectiva hebrea y cristiana, detrás tanto del día que profiere su palabra al día $-\mathrm{y}$ aquí podemos entender «día» como «la experiencia vivida por el ser humano en el curso del día»como de la noche que le enseña sabiduría a la noche, se encuentra el Dios trascendente. La experiencia diurna, personal y social, es un don divino que vivimos durante el día, y cuyo sentido meditamos en el curso de la noche. Ese sentido que la noche nos permite vislumbrar con claridad es la verdad revelada, repleta de significación, que Dios nos comunica en nuestra meditación nocturna para alimentar espiritualmente nuestra conciencia y guiar nuestros pasos en este mundo.

En un mundo secularizado, a solas el hombre con su experiencia y su conciencia, reducida a su propia y solipsista fisiología subjetiva, resulta más necesaria que nunca una poesía como la de José Alcalá-Zamora. En sus deslumbrantes revelaciones liricas reconocemos primero la veracidad de una conciencia intensamente personal e idiosincrática; y, por otro lado, nos reconocemos a nosotros mismos en la relación veraz de una experiencia común que todos compartimos con el poeta, en el día a día que nos confiere a todos una misma palabra.

\section{Bibliografía}

AlCAlÁ-Zamora, José (2012): Noticia de mí. Ed. Ángel Gómez Moreno. Madrid, Sial.

BÉGUIN, Albert (1937): El alma romántica y el sueño. Trad. Mario Monteforte Toledo. México, Fondo de Cultura Económica, 1978.

BIBLIA SACRA (1983): Biblia Sacra iuxta vulgatam versionem. Stuttgart, Deutsche Bibelgesellschaft. 
SÁNCHEZ MARTínEZ de PinILlos, Hernán (2015): «Noticia de mí: La poesía de José Alcalá-Zamora»,

Studia Ibérica et Americana. Journal of Iberian and Latin American Literary and Cultural Studies, 2, pp. 974-993.

SHELley, Percy Bysshe (1821): A Defence of Poetry, en Selected Prose Works of Shelley. Londres, Watts \& Co., 1915.

VERLAINE, Paul (1884): «Art poétique», en Jadis et naguère. París, Léon Vanier. 